\title{
Survey and Dynamics of bacteria involved in secondary infections in sheep affected by orf virus
}

\author{
Elisabeta PASTOR ${ }^{1 *}$, Petru POJAR ${ }^{1}$, Crinu MESTESANU ${ }^{2}$, Marina SPÎNU ${ }^{1}$ \\ ${ }^{1}$ Faculty of Veterinary Medicine ,University of Agricultural Sciences and Veterinary Medicine, Cluj- \\ Napoca, Romania \\ ${ }^{2}$ Veterinary doctor, Santău, Romania \\ *corresponding author: mestesanu.elisabeta-sm@ansvsa.ro
}

Bulletin UASVM Veterinary Medicine 77(2)/2020

Print ISSN 1843-5270; Electronic ISSN 1843-5378

doi:10.15835/buasvmcn-vm:2020.0024

\begin{abstract}
In recent decades, secondary infection bacteria quickly increased their pathogenicity in both human and veterinary patients, due to their continuously increasing antibiotic-resistance. When such bacteria intervene in infections as orf in sheep, they can determine an important impact either in the sanitary or in the economic aspect of the brreding sector. Considering the relatively high spread and economic impact of orf in Romanian sheep, this research aimed to estimate the complexity of the secondary infections in diseased sheep in connection with the severity of the lesions displayed. The research was conducted in five herds, on 3 to 96 month old sheep, with orf lesions, scored from mild to severe. The bacteria were isolated from the lesions and identified by cultivation on broth and agar plates plus identification by use of API galleries. The severity of the lesions did not seem to be influenced by the number of bacterial species isolated, but by the herd environment and individual pathogenicity of the isolates.
\end{abstract}

Keywords: secondary infection bacteria, dynamics, orf, sheep

\section{Introduction}

Parapoxviruses are epitheliotropic viruses that affect a wide range of domestic and wild animals, even humans (Hosamani et al., 2007).

We can say that this virus is an opportunistic pathogen because it is often associated with other viral infections such as peste des petits ruminants or smallpox virus (Saravanan et al., 2007). Infections with this virus develop mainly local infections such epidermitis that progresses rapidly through the stages of erythema, papule, vesicle, pustule with crusts characteristic to Parapoxvirus infections (Hosamani et al., 2009). Contagious ecthyma is a zoonosis affecting humans too, especially people in contact with infected animals, the clinical signs consisting of acute skin lesions, malaise and lymphadenopathy (Groves et al., 1991). In immunodeficient patients have been reported severe cases (Ara et al., 2008). Among the complications following orf infection can be mentioned bacterial mastitis which can even lead to gangrenous mastitis. Also complications such as secondary necrobacillosis are possible, leading to lameness and economical losses ( http://www.msdvetmanual.com/integumentarysystem/contagious-ecthyma/overview-ofcontagious-ecthyma). Necrobacillosis is a serious infectious disease caused by an anaerobic bacteria Fusobacterium Necrophorum associated or not with Corynebacteriun Pyogenes, and produces primary interdigital lesions, the deformation of the hooves then affecting even the joints of the animal that can no longer feed properly (http: //. edu / cgi / viewcontent.cgi? article $=1994 \&$ 
context $=$ iowastate_veterinarian). In rare cases, digestive cases or hepatic necrobacillosis or even transmission to the fetus can occur, producing dermatitis or suppurative bronchopneumonia in the fetus (Handeland et al.2007). Other secondary infections may be with Staphylococcus Aureus and Arcanobacterium pyogenes (Housawi et al., 2000) or infections with papillomatosis virus, smallpox virus or fungi (Wilson et al. 2002). The treatment of orf depends on the severity of the infection and healing can last from a few weeks to 3-6 months in complicated cases with secondary infections (Demiraslan et al. 2017). There is no specific treatment, but just topic disinfection of the lesions (Bora et al. 2015).

\section{Materials and methods}

The research was conducted in five herds, on 3 to 96 month old sheep, with orf lesions, scored from mild (1) to severe (3). The bacteria were isolated from the lesions and identified by cultivation on liquid and solid media plus identification by use of API galleries with related software. The biological material was collected from 5 flocks of sheep from Santău, Romania. The samples have been colletected from animals belonging to Turcana, Merinos and Ile de France breeds, mostly young both males and females. In the case studied, the lesions appeared on the lips, nostrils, and nipple, with a tendency to expand on the mucosa in some cases. To perform bacteriological procedures exsudate has been collected from the lesions with sterile tampons soaked in sterile physiological solution and stored in sterile recipients. Biological materials have been transported refrigerated to the animal and food health laboratory Satu Mare for the analyses, in order to detect the bacterial flora involved in secondary infections. The transport was carried out avoiding thermal or other shocks, in Amies transport medium. Transport medium do not contain a rich substrate for the multiplication of bacteria, but they can provide the necessary support to survive during transportation and manipulations that precede bacteriological determinations. Ninetysix samples were collected carefully avoiding contamination with other infectious agents, carrying attention on preventing their desiccation or prolonged exposure to air, processing being carried out on the same day of the collection.
In order to perform statistical determinations, the severity of clinical signs has been shown in lesion scores: 1-mild, 2-moderate, 3-severe. Also for the sex of the animals we used scores 1 -for males and 2 for females. To detect secondary infection flora we used the classic becterioscopic and bacteriological methods. Depending on the bacteria observed when examining direct smears, we used the Gram staining method to highlight the gram negative and gram positive bacteria. In addition, we used the method with malachite green, to highlight the sporogenesis and staining of the capsule with Congo Red. The results of the bacterioscopic examination provide information to guide us further to perform bacteriological examination and biochemical tests that will accurately identify the existing flora. Depending on the results of the bacterioscopic examination, we used simple, selective, special media to examine the cultural and biochemical characteristics of the isolated bacteria. Additionally, API galleries have been used, the results of which were read in the MiniApi device.

For the statistical determinations we used the Graphpad Prism 8 application, in order to observe the evolution of the obtained values.

\section{Results}

A number of 96 samples were collected in order to reveal secondary infections, of which 40 turned out to carry bacteria as follows in table no.1.

Following bacteriological and biochemical examination, the presence of Staphylococcus aureus, Corynebacterium pseudotuberculosis, Bacillus cereus and Pseudomonas aeruginosa was detected (Table 1). Following the laboratory procedures, in 40 samples out of 96 were detected secondary infections (Figure 1). In 29 samples the presence of S.aureus has been demonstred, while in 5 samples C. pseudotuberculosis, in 7 samples B.cereus and in 9 samples Paeruginosa. Out of 40 samples showing bacterial presence, in 12 were isolated two bacteria at the same time.

Globally, the presence of Saureus was the most common, followed by Paeruginosa (Figure 2). Since these two bacteria are ubiquitous and very resistant in the environment, the percentage obtained is not surprising. Being both opportunistic bacteria causing infections, they can have easy access created by lesions determined by orf virus and multiply in these sites. 
Table 1. Samples showing secondary bacterial infections

\begin{tabular}{|c|c|c|c|c|c|}
\hline Herd & Sample no. & $\operatorname{Sex}^{* *}$ & Age & Lesion score* & Isolated bacteria \\
\hline 1 & 1 & 2 & 8 & 3 & S.aureus - P.aeruginosa \\
\hline 1 & 3 & 2 & 8 & 3 & S.aureus \\
\hline 1 & 4 & 2 & 8 & 2 & S.aureus-B.cereus \\
\hline 1 & 6 & 2 & 3 & 3 & S.aureus-B.cereus \\
\hline 1 & 9 & 2 & 3 & 3 & S. aureus \\
\hline 1 & 12 & 2 & 3 & 3 & S.aureus-B.cereus \\
\hline 1 & 15 & 2 & 3 & 2 & S.aureus-B.cereus \\
\hline 1 & 16 & 2 & 3 & 3 & S.aureus \\
\hline 1 & 21 & 2 & 3 & 3 & S.aureus \\
\hline 1 & 29 & 1 & 16 & 1 & C. pseudotuberculosis \\
\hline 1 & 33 & 1 & 16 & 1 & B.cereus-P.aeruginosa \\
\hline 1 & 35 & 1 & 16 & 3 & S.aureus-P.aeruginosa \\
\hline 1 & 42 & 2 & 48 & 3 & S.aureusP.aeruginosa \\
\hline 1 & 45 & 2 & 48 & 3 & C.pseudotuberculosis-S.aureus \\
\hline 2 & 49 & 2 & 5 & 3 & S.aureus \\
\hline 2 & 52 & 2 & 5 & 3 & S.aureus \\
\hline 2 & 55 & 2 & 5 & 3 & C.pseudotuberculosis \\
\hline 2 & 56 & 2 & 5 & 3 & S.aureus-P.aeruginosa \\
\hline 2 & 59 & 2 & 120 & 3 & P.aeruginosa \\
\hline 2 & 66 & 2 & 4 & 3 & S.aureus \\
\hline 3 & 71 & 1 & 4 & 2 & S.aureus-B.cereus \\
\hline 3 & 73 & 2 & 4 & 3 & S.aureus-C.pseudotuberculosis \\
\hline 3 & 74 & 2 & 48 & 1 & B.cereus \\
\hline 3 & 75 & 2 & 48 & 3 & S.aureus \\
\hline 3 & 76 & 2 & 48 & 2 & S.aureus \\
\hline 4 & 77 & 1 & 4 & 3 & S.aureus \\
\hline 4 & 78 & 1 & 4 & 1 & S.aureus \\
\hline 4 & 79 & 2 & 4 & 3 & S.aureus \\
\hline 4 & 80 & 2 & 3 & 3 & S.aureus \\
\hline 4 & 81 & 2 & 3 & 3 & P.aeruginosa \\
\hline 4 & 82 & 2 & 3 & 3 & S.aureus \\
\hline 4 & 84 & 2 & 96 & 3 & C.pseudotuberculosis \\
\hline 4 & 85 & 2 & 60 & 1 & S.aureus \\
\hline 4 & 86 & 2 & 60 & 3 & P.aeruginosa \\
\hline 5 & 87 & 2 & 96 & 2 & S.aureus \\
\hline 5 & 88 & 2 & 72 & 3 & S.aureus \\
\hline 5 & 91 & 1 & 4 & 3 & S.aureus \\
\hline 5 & 93 & 2 & 4 & 3 & S. aureus \\
\hline 5 & 94 & 2 & 4 & 3 & P.aeruginosa \\
\hline 5 & 96 & 1 & 4 & 2 & C.pseudotuberculosis \\
\hline
\end{tabular}

Note* lesion scores that show severity of the simptomes, ${ }^{* *}$ Scores according to sex of the animals saples came from 


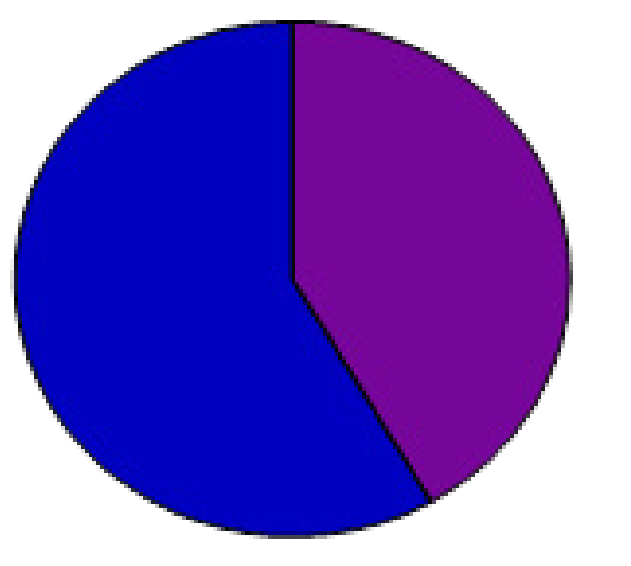

$41.67 \%$ With secondary infections
$58.33 \%$ No secondary infections

\section{Total $=96$}

Figure 1. Percentage of secondary infections detected in the analyzed samples
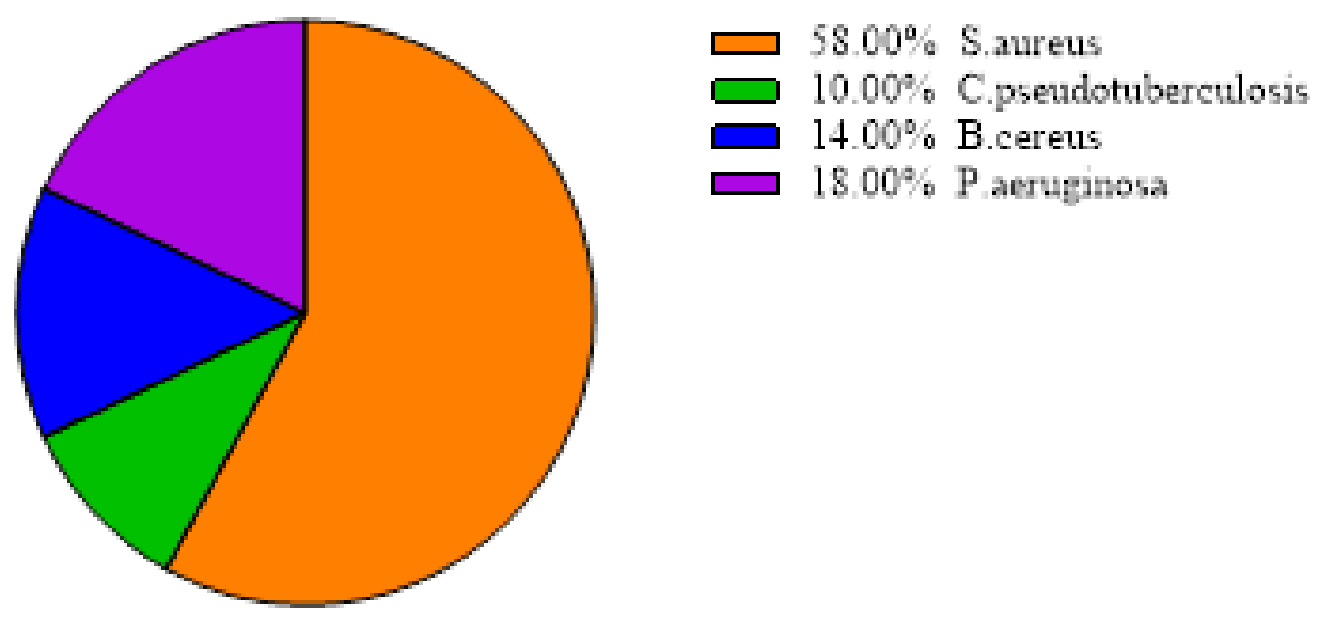

Figure 2. Percentage of the bacteria species detected in the samples with secondary infections

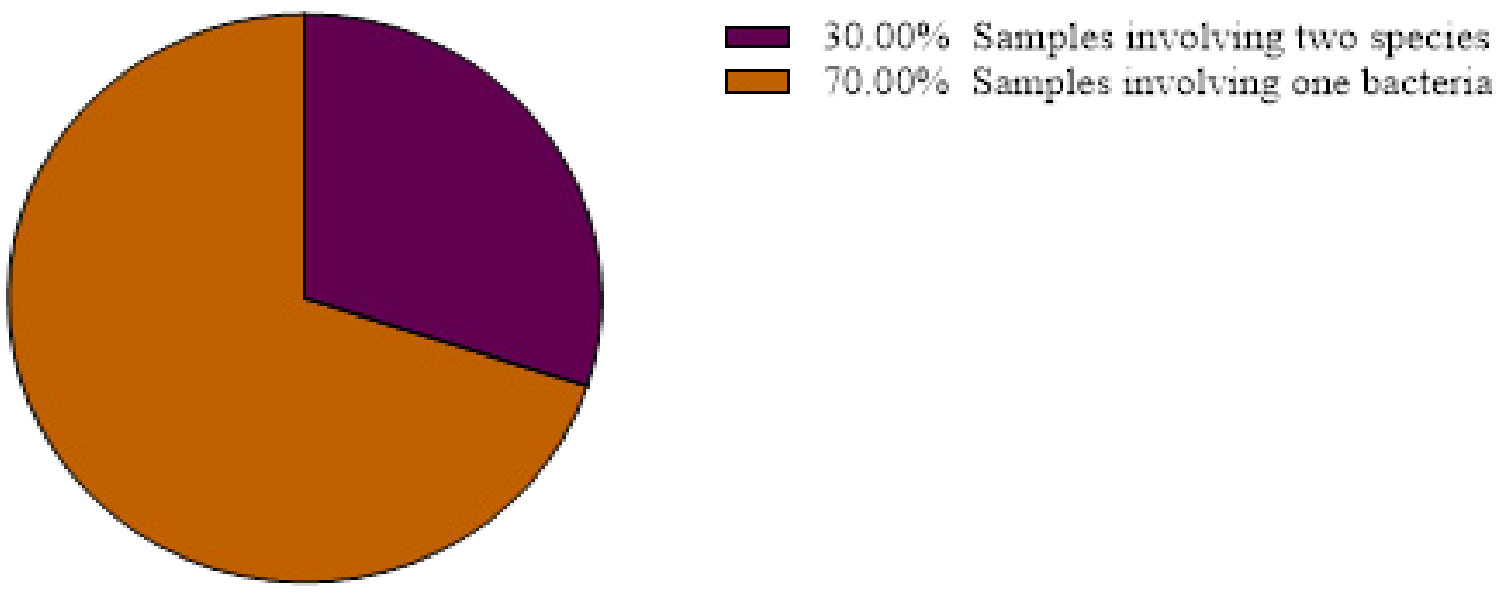

Figure 3. Percentage of secondary infections involving two bacterias 
From the total of 40 samples with bacterial suprainfecions in a number of 12 samples, the existence of two bacteria was found (Figure 3 ). The highest number of secondary infections involving two bacteria were in herd no.1 in proportion of $57.14 \%$ and in herd no. 3 in proportion of $40 \%$.

The ages of sheep with secondary infections ranged from 3 to 120 months, with an average of 23 months. However, the coefficient of variation and the standard deviation indicate a large variability of ages, at 95\% significance level. The same trend was observed when calculating the average ages at each herd, the average ages were different from the global average, but the coefficients of variation and standard deviations indicated the same high variability of ages (Table 2). This explains that regardless of the age of the animals, secondary infections can occur if favorable conditions are met.

Regarding the distribution of secondary infections by sex in affected animals, lesion scores indi- cated a trend of secondary infections in females in herds no. 1, 2, 3, 4 fact supported by the coefficients of variation, at a level of significance of $95 \%$. The exception is represented by herd no. 5 where the occurrence of secondary infections was variable involving both males and females. In this case the coefficient of variation whith a significance level of $95 \%$ showed a high variability of the sexes. The trend of secondary infections at global level involved mostly females in bacterial suprainfections (Table 3).

Secondary infections with S.aureus predominated in every herd, the percentages varying between $52.17 \%$ and $66.67 \%$. In the case of Paeruginosa the percentages were different between the herds and there was one herd in which its presence was not detected.. C. pseudotuberculosis was present in all herds with the exception of herd no., while 1. B.cereus was isolated only in the herds 1 and 3 (Table 4).

Table 2. Age ditribution (in months) of the animals with secondary infections and statistic analysis

\begin{tabular}{ccccccc}
\hline Descriptive statistics & $\begin{array}{c}\text { Herd } \\
\text { no.1 }\end{array}$ & $\begin{array}{c}\text { Herd } \\
\text { no.2 }\end{array}$ & Herd no.3 & $\begin{array}{c}\text { Herd } \\
\text { no.4 }\end{array}$ & $\begin{array}{c}\text { Herd } \\
\text { no.5 }\end{array}$ & Global \\
\hline Minimum & 3 & 4 & 4 & 3 & 4 & 3 \\
\hline Maximum & 48 & 120 & 48 & 96 & 96 & 120 \\
Mean & 13 & 24 & 30 & 26 & 31 & 23 \\
\hline Std. Deviation & 16 & 47 & 24 & 36 & 42 & 31 \\
\hline Std. Error of Mean & 4,2 & 19 & 11 & 12 & 17 & 4,9 \\
\hline Lower 95\% CI of mean & 4,3 & -25 & 0,48 & $-1,2$ & -13 & 13 \\
\hline Upper 95\% CI of mean & 22 & 73 & 60 & 54 & 75 & 33 \\
\hline Coefficient of variation & $117 \%$ & $196 \%$ & $79 \%$ & $136 \%$ & $137 \%$ & $138 \%$ \\
\hline
\end{tabular}

Table 3. Distribution of secondary infections amongst sex of the affected animal

\begin{tabular}{ccccccc}
\hline Descriptive statistics & Herd no.1 & Herd no.2 & Herd no.3 & Herd no.4 & Herd no.5 & Global \\
\hline Mean & 1,8 & 2 & 1,8 & 1,8 & 1,7 & 1,8 \\
Std. Deviation & 0,43 & 0 & 0,45 & 0,44 & 0,52 & 0,41 \\
Std. Error of Mean & 0,11 & 0 & 0,2 & 0,15 & 0,21 & 0,064 \\
Lower 95\% CI of mean & 1,5 & 2 & 1,2 & 1,4 & 1,1 & 1,7 \\
Upper 95\% CI of mean & 2 & 2 & 2,4 & 2,1 & 2,2 & 1,9 \\
Coefficient of variation & $24 \%$ & $0,0 \%$ & $25 \%$ & $25 \%$ & $31 \%$ & $23 \%$ \\
\hline
\end{tabular}


Table 4. Percentage of isolated microflora in each herd

\begin{tabular}{lccccc}
\hline \multicolumn{1}{c}{ Bacteria involved } & Herd no.1 & Herd no.2 & Herd no.3 & Herd no.4 & Herd no.5 \\
\hline S.aureus & $52,17 \%$ & $57,14 \%$ & $57,14 \%$ & $66,67 \%$ & $66,67 \%$ \\
C.pseudotuberculosis & $8,70 \%$ & $14,29 \%$ & $14,29 \%$ & $11,11 \%$ & $16,67 \%$ \\
B.cereus & $21,73 \%$ & $0 \%$ & $28,57 \%$ & $0 \%$ & $0 \%$ \\
P.aeruginosa & $17,39 \%$ & $28,57 \%$ & $0 \%$ & $22,22 \%$ & $16,67 \%$ \\
\hline
\end{tabular}

Table 5. Lesion scores in each herd and at global level.

\begin{tabular}{lcccccc}
\hline Minimum & 1 & 3 & 1 & 1 & 2 & 1 \\
Maximum & 3 & 3 & 3 & 3 & 3 & 3 \\
\hline Mean & 2,6 & 3 & 2,2 & 2,6 & 2,7 & 2,6 \\
\hline Std. Deviation & 0,76 & 0 & 0,84 & 0,88 & 0,52 & 0,71 \\
Std. Error of Mean & 0,2 & 0 & 0,37 & 0,29 & 0,21 & 0,11 \\
\hline Lower 95\% CI of mean & 2,1 & 3 & 1,2 & 1,9 & 2,1 & 2,4 \\
\hline Upper 95\% CI of mean & 3 & 3 & 3,2 & 3,2 & 3,2 & 2,8 \\
\hline Coefficient of variation & $29 \%$ & $0,0 \%$ & $38 \%$ & $35 \%$ & $19 \%$ & $27 \%$ \\
\hline
\end{tabular}

Table 6. ONE Way ANOVA and Dunnett's multiple comparisons test between general lesion scores and scores obtained in every herd.

\begin{tabular}{lcccc}
\hline \multicolumn{1}{c}{ Model comparison } & $\begin{array}{c}\text { Probability it } \\
\text { is correct }\end{array}$ & & \\
\hline $\begin{array}{l}\text { Null H. All population } \\
\text { means identical }\end{array}$ & $98 \%$ & & & \\
\hline $\begin{array}{l}\text { Alternative H: Distinct } \\
\text { population means }\end{array}$ & $2,1 \%$ & & & \\
\hline $\begin{array}{l}\text { Dunnett's multiple } \\
\text { comparisons test }\end{array}$ & Mean Diff & $\begin{array}{c}\text { 95,00\% CI } \\
\text { of diff }\end{array}$ & Significant? & $\begin{array}{c}\text { Adjusted } \\
\text { P Value }\end{array}$ \\
Global vs. Herd no.1 & 0,071 & $-0,53$ to 0,67 & No & 0,9986 \\
Global vs. Herd no.2 & $-0,36$ & $-1,2$ to 0,47 & No & 0,753 \\
\hline Global vs. Herd no.3 & 0,44 & $-0,45$ to 1,3 & No & 0,6366 \\
Global vs. Herd no.4 & 0,087 & $-0,62$ to 0,79 & No & 0,9984 \\
\hline Global vs. Herd no.5 & $-0,024$ & $-0,85$ to 0,80 & No & $>0,9999$ \\
Test details & Mean 1 & Mean 2 & Mean Diff, & SE of diff, \\
Global vs. Herd no.1 & 2,6 & 2,6 & 0,071 & 0,23 \\
Global vs. Herd no.2 & 2,6 & 3 & $-0,36$ & 0,31 \\
\hline Global vs. Herd no.3 & 2,6 & 2,2 & 0,44 & 0,34 \\
\hline Global vs. Herd no.4 & 2,6 & 2,6 & 0,087 & 0,27 \\
Global vs. Herd no.5 & 2,6 & 2,7 & $-0,024$ & 0,31 \\
\hline
\end{tabular}


The average values of the lesion scores at the level of all samples were around 2.6, which means that in the whole population there is a tendency towards a severe evolution, the coefficient of variation $(27 \%)$ obtained indicates that the average values of the population are around the average value of 2.6 (Table 5). The average values recorded separately for each herd were between 2.2 and 3 . All values were above the value of 2.5 indicating averages that tend towards a severe evolution, except for herd no.3 where an average of 2.2 was calculated but at a significance level of $95 \%$ scores are variable between scores indicating moderate and severe lesions. In order to evaluate the evolution trends, the coefficients of variation were also calculated (see table no.3). In the case of herds no. 1, 3 and 4 the coefficients of variation, at a significance level of $95 \%$, were higher than $25 \%$ meaning that the trend of the average population tends to vary.

The values for herds no.2 and no.5, however, tended to group around the averages indicating score 3.

To evaluate the differences between scores in ech flock and scores obtained at global level, we used the One Way ANOVA test. Were compared the averages obtained in herds with the average of the entire batch of samples. The test confirmed the null hypothesis, namely that the herd averages tend to be equal to the averages of the whole batch of samples with a probability of $98 \%$ (Table 6 ). The smallest differences were found when comparing the values in the case of herds no.1,4, 5. For multiple comparisons Dunnetts multiple comparisons test was used showing almost insignificant differences between global values and herds 1, 4, 5 .

Table 7 shows the values of comparisons between the values of lesional scores, the difference between the averages being very close to the value 0 in the case of comparisons between herd no.1 and herds 4 and 5. And in this case the probability of population averages trend to be equal was $96 \%$. Comparisons between herd no.1 and herd no.4 and 5 showed a very small difference and higher difference between herd no. 2 and 3.The $p$ value higher than $\alpha=0,05$ showed that differences between herds were small having a trend to be equal.

Correlation between the individual characteristics of sheep such as sex, lesion score and age proved that at a $95 \%$ confidence level there is no correlation between sex, lesion score and the number of bacteria isolated (see Table 8). A very weak correlation was observed between age and the number of isolated bacteria, in the sense that at small ages the trend to become infected with two bacteria increases. But the value of $\mathrm{P}$ that is not less than 0.05 indicates that we cannot generalize, and this slight negative correlation is because can be attributed to acoincidence.

For the same reason, Pearsons correlation was performed in each herd.Thereby in herd no. 1 there was no correlation between lesion scores, sex, age and the number of species of bacteria that caused secondary infections in one sample. But $\mathrm{P}$ values higher than 0,05 suggest that at a 95\% confidence level we cannot generalize and secondary infections with two bacteria at once can be infuenced by other factors (see table 9 ).

In flocks 2, 4 and 5, the correlation coefficient did not return any results, indicating that there is no link between age, sex, lesion scores and the number of bacteria that populate the orf lesions..

In herd no. 3 , however, there was a reasonable correlation between lesion scores and the number of isolated bacteria and a strong negative correlation between age and the number of isolated bacteria. Thus in herd no. 3 it was observed the existence of a trend that number of bacterial species populating lesions to influence the evolution of lesion scores. At the same time, as age decreases, the tendency to contract two bacteria increases. In this case the values of P were higher than 0,05 indicating that these trends were due to chance and results are valid only for herd no.3 (Table 10). Correlations between age and number of species that cause secondary infections returned no results, the two parameters evolving totally independently one from the other.

\section{Discussion and Conclusions}

Following the determinations, we found that $S$. aureus and $P$. aeruginosa dominated in secondary infections, underlying their highly infectious character if they encounter a breach in the organism (Zecconi and Scali, 2013). Contagious ecthyma being a disease that affects the skin, it creates breaches for $S$. aureus and can complicate the evolution of this disease (Chi et al., 2017). Being a bacteria that easily adapts to any biological environment can even cause treatment-resistant rebellious mastitis (Weese et 
Table 7. Anova comparisons and Dunnet's multiple comparisons test results between herds

\begin{tabular}{|c|c|c|c|c|}
\hline Model comparison & $\begin{array}{l}\text { Probability } \\
\text { it is correct }\end{array}$ & & & \\
\hline $\begin{array}{l}\text { Null H. All population } \\
\text { means identical }\end{array}$ & $96 \%$ & & & \\
\hline $\begin{array}{l}\text { Alternative } \mathrm{H} \text { : Distinct } \\
\text { population means }\end{array}$ & $4 \%$ & & & \\
\hline $\begin{array}{l}\text { Tukey's multiple } \\
\text { comparisons test }\end{array}$ & Mean Diff & $\begin{array}{l}95,00 \% \\
\text { CI of diff }\end{array}$ & Significant? & $\begin{array}{l}\text { Adjusted } \\
\text { P Value }\end{array}$ \\
\hline Herd no.1 vs. Herd no.2 & $-0,43$ & $-1,4$ to 0,57 & No & 0,733 \\
\hline Herd no.1 vs. Herdno.3 & 0,37 & $-0,70$ to 1,4 & No & 0,8535 \\
\hline Herd no.1 vs. Herd no.4 & 0,016 & $-0,86$ to 0,89 & No & $>0,9999$ \\
\hline Herd no.1 vs. Herd no.5 & $-0,095$ & $-1,1$ to 0,90 & No & 0,9987 \\
\hline Herd no. 2 vs. Herd no.3 & 0,8 & $-0,44$ to 2,0 & No & 0,3606 \\
\hline Herd no. 2 vs. Herd no. 4 & 0,44 & $-0,64$ to 1,5 & No & 0,7609 \\
\hline Herd no. 2 vs. Herd no.5 & 0,33 & $-0,85$ to 1,5 & No & 0,9258 \\
\hline Herd no. 3 vs. Herd no.4 & $-0,36$ & $-1,5$ to 0,79 & No & 0,8971 \\
\hline Herd no.3 vs. Herd no.5 & $-0,47$ & $-1,7$ to 0,77 & No & 0,8149 \\
\hline Herd no.4 vs. Herd no.5 & $-0,11$ & $-1,2$ to 0,97 & No & 0,9982 \\
\hline Test details & Mean 1 & Mean 2 & Mean Diff, & SE of diff, \\
\hline Herd no.1 vs. Herd no. 2 & 2,6 & 3 & $-0,43$ & 0,35 \\
\hline Herd no.1 vs. Herdno.3 & 2,6 & 2,2 & 0,37 & 0,37 \\
\hline Herd no.1 vs. Herd no.4 & 2,6 & 2,6 & 0,016 & 0,3 \\
\hline Herd no.1 vs. Herd no.5 & 2,6 & 2,7 & $-0,095$ & 0,35 \\
\hline Herd no. 2 vs. Herd no. 3 & 3 & 2,2 & 0,8 & 0,43 \\
\hline Herd no. 2 vs. Herd no.4 & 3 & 2,6 & 0,44 & 0,38 \\
\hline Herd no. 2 vs. Herd no.5 & 3 & 2,7 & 0,33 & 0,41 \\
\hline Herd no.3 vs. Herd no.4 & 2,2 & 2,6 & $-0,36$ & 0,4 \\
\hline Herd no. 3 vs. Herd no. 5 & 2,2 & 2,7 & $-0,47$ & 0,43 \\
\hline Herd no.4 vs. Herd no.5 & 2,6 & 2,7 & $-0,11$ & 0,38 \\
\hline
\end{tabular}

Table 8. Correlation between individual characteristics and the number of bacteria isolated at global level

\begin{tabular}{cccc}
\hline Pearsons correlation & $\begin{array}{c}\text { Lesion scores vs. Number } \\
\text { of bacterial species } \\
\text { isolated in a sample }\end{array}$ & $\begin{array}{c}\text { Sex vs. Number } \\
\text { of bacterial } \\
\text { species isolated }\end{array}$ & $\begin{array}{c}\text { Age vs. Number } \\
\text { of bacterial } \\
\text { species isolated }\end{array}$ \\
\hline r & $-0,048$ & $-0,11$ & $-0,24$ \\
\hline $\mathbf{9 5 \%}$ confidence interval & $-0,35$ to 0,27 & $-0,41$ to 0,21 & $-0,51$ to 0,080 \\
\hline R squared & 0,0023 & 0,013 & 0,057 \\
\hline P (two-tailed) & 0,7687 & 0,4915 & 0,1395 \\
\hline
\end{tabular}

Note: Correlations are being calculated at a $95 \%$ level of significance, $P$ values higher then 0,05 indicating that correlations beween the two sets of values cannot be generalized and every correlation between two datasets is the result of hazard

r- correlation coefficient 
Table 9. Correlations of individual factors with the number of isolated bacteria in herd no.1

\begin{tabular}{cccc}
\hline Pearsons correlation & $\begin{array}{c}\text { Lesion scores vs. } \\
\text { Number of bacterial } \\
\text { species isolated } \\
\text { in a sample }\end{array}$ & $\begin{array}{c}\text { Sex vs. Number of } \\
\text { bacterial species } \\
\text { isolated }\end{array}$ & $\begin{array}{c}\text { Age vs. Number of } \\
\text { bacterial species isolated }\end{array}$ \\
\hline $\mathbf{r}$ & $-0,11$ & $-0,1$ & $-0,012$ \\
$\mathbf{9 5 \%}$ CI & $-0,61$ to 0,44 & $-0,60$ to 0,45 & $-0,54$ to 0,52 \\
\hline R squared & 0,013 & 0,01 & 0,00015 \\
\hline P & 0,6999 & 0,7325 & 0,9665 \\
\hline
\end{tabular}

Note: Correlations are being calculated at a 95\% level of significance, P values higher then 0,05 indicating that correlations beween the two sets of values cannot be generalized and every correlation between two datasets is the result of hazard r- correlation coefficient

Table 10. Correlations of individual factors with the number of isolated bacteria in herd no.3

\begin{tabular}{ccc}
\hline Pearsons correlation & $\begin{array}{c}\text { Lesion scores vs. Number } \\
\text { of bacterial species } \\
\text { isolated in a sample }\end{array}$ & $\begin{array}{c}\text { Sex vs. Number of bacterial } \\
\text { species isolated }\end{array}$ \\
\hline $\mathbf{r}$ & 0,33 & $-0,61$ \\
$\mathbf{9 5 \%}$ confidence interval & $-0,78$ to 0,94 & $-0,97$ to 0,59 \\
R squared & 0,11 & 0,38 \\
\hline
\end{tabular}

Note: Correlations are being calculated at a 95\% level of significance, P values higher then 0,05 indicating that correlations beween the two sets of values cannot be generalized and every correlation between two datasets is the result of hazard r- correlation coefficient.

al., 2010). As mentioned by Mombeni et al., 2013 and Venkatesan et al., 2014, secondary infections with $S$. aureus, are among the most common forms of suprainfection, in orf episodes as confirmed in this study. This is also underlined by the fact that secondary infections with $S$. aureus also predominated in every single flock, not only at global level. Paeruginosa that is a very versatile and resistant bacterium, due to its capsule, was as well very present in secondary infections, but was not detected in all herds. Since they cause abscesses, abortions and other lesions that are very difficult to heal (Quinn et al., 2011) increases the concern, especially since these bacteria are rebellious to antibiotic therapy (Kerr et al., 2009). The different distribution of bacteria highlighted in the herds was probably due to the microbism present in each flock. Even if in two herds it was observed the existence of a link between sex and the severity of clinical signs and the number of bacteria detected in lesions (herd no.3) and between age and the number of species of bacteria found (herd no.1), at global level, there were no correlations between these parameters. We can thus say that there is no connection between the sex, age or severity of the lesions and the number of species of bacteria that infect lesions caused by orf virus. Lesional scores of sheep with suprainfected orf lesions tended to cluster around 2 and 3 confirming that the bacteria that populate such lesions also complicate the course of the disease as noted by Fleming et al., 2015 and Chi et al., 2017. However, as regards sex of the affected animals, females seemed to be more susceptible to a secondary infection, probably due to the fact that the disease developed in late spring, during the shearing when the stress caused by lamb suckling and shearing can decrease the immunity of mothers. There was no connection between sex and number of bacteria causing secondary infections. 
As shown in literature (Chi et al., 2017, Quinn et al., 2011) orf virus can create breaches for opportunistic bacteria to develop secondary bacterial infections. In our study study is stated that such bacterial infections can often occur, regarding that all 4 baterial species isolated can develop infections if they encounter discontinuities in natural barriers of the hosts. To avoid such infections prevention measures should be used such as isolating affected sheep, disinfection of the lesions and antibiotical prevention if it is necessary.

Acknowledgments. This research did not receive any specific grant from funding agencies of the public, commercial, or not-for-profit sectors.

\section{References}

1. Ara M, Zaballos P, Sanchez M, Querolet I, Zubiri ML, Simal E, Horndler C (2008). Giant and recurrent orf virus infection in a renal transplantrecipient treated with imiquimod. J Am Acad Dermatol, 58:39-40.

2. Bora DP, Barman NN, Das SK, Bhanuprakash V, Yogisharadhya R, Venkatesan G, (2012). Identification and phylogenetic analysis of orf viruses isolated from outbreaks in goats of Assam, a northeastern state of India. Virus Genes., 45(1):98-104.

3. Chi X, Zeng X, Luo S (2017). Diagnosis and phylogenetic analysis of a multifocal cutaneous Orf virus with mixed bacterial infection outbreak in goats in Fujian province, China. Arch. Virol., 162(10), DOI: 10.1007/s00705-0173424-z.

4. Demiraslan H, Dinc G, Doganay M (2017). An Overwiev of ORF Virus Infection in Humans and Animals. Recent Pat Antiinfect Drug Discov., 12(1):21-30.

5. Mombeni EG, Gharib M, Mombeini HR, Varshovi M, Khalaj M, Kenarkohi M, Goudarzi SM, Mousavi N (2013). Outbreak of contagious ecthyma in camels (Camelus dromedarius and Camelus bactrianus) in Southwest Iran, Revue d'élevage et de médecine vétérinaire des pays tropicaux

6. Fleming SB, Wise LM, Mercer AA (2015). Molecular genetic analysis of orf virus: A poxvirus that has adapted to skin. Viruses, 7(3):1505-1539.

7. Groves R, MacDonald DM, Jones EW (1990). Human orf. Arch dermatol, 126:1649.
8. Handeland $\mathrm{K}$, Boye $\mathrm{M}$, Bergsjø B, Bondal $\mathrm{H}$, Isaksen $\mathrm{K}$, Agerholm JS (2010). Digital necrobacillosis in Norwegian wild tundra reindeer (Rangifer tarandus tarandus). J Comp Pathol., 143: 29-38.

9. Hosamani M, Scagliarini A, Bhanuprakash V, McInnes CJ, Singh RK (2009). Orf:An update on current research and future perspectives, Expert Rev. Anti Infect. Ther, 7(7):879-93.

10. Hosamani M, Yadav S, Kallesh DJ, Mondal B, Bhanuprakash V, Singh RK (2007). Isolation and characterization of an indian orf virus virus from goats. Zoonoses Public Health, 54:204-208.

11. Housawi FMT, Abu Elzein EME (2000). Contagious ecthyma associated with myiasis in sheep, Rev. Sci. Tech. Off. int. Epiz.,19(3):863-866.

12. Kerr KG and Snelling AM (2009). Pseudomonas aeruginosa: a formidable and ever-present adversary. Journal of Hospital Infection, 73:338-344.

13. Nandi S, De UK, Chowdhury S (2011). Current status of contagious ecthyma or orf disease in goat and sheep-A global perspective, Small Ruminant Research, 96(23):73-82.

14. Quinn PJ, Markey BK, Leonard C, FitzPatrick ES, Fanning S, Hartigan PJ (2011). Veterinary Microbiology and Microbial Disease, Blackwell Publishing ltd. , 593-596

15. Saravanan P, Balamurugan JB, Sen A, Sarkar J, Sahay V, Rajak KK, Hosamani M, Yadav MP, Singh RK (2007). Mixed infection of peste des petits ruminants and Orf on a goat farm in Shahjahanpur. India. Vet. Rec., 160: 410-412.

16. Venkatesan G, Balamurugan V, Bhanuprakash V (2014). Multiplex PCR for simultaneous detection and differentiation of sheeppox, goatpox and orf viruses from clinical samples of sheep and goats. J Virol Methods, 195:1-8.

17. Weese JS, van Duijkeren E (2010). Methicillinresistant Staphylococcus aureus and Staphylococcus pseudintermedius in veterinary medicine. Veterinary Microbiology, 27: 418-429.

18. Wilson DJ, McFarlane L (2012). Contagious ecthyma in a Rocky Mountain bighorn sheep from Utah. HumanWildlife Interactions, 6(1):7-11.

19. Zecconi A, Scali F (2013). Staphylococcus aureus virulence factors in evasion from innate immune defenses in human and animal diseases. Immunology Letters, 150 (1-2):1222.

20. http://lib.dr.iastate.edu/cgi/viewcontent.cgi?article=199 4\&context=iowastate_veterinarian

21. http://www.msdvetmanual.com/integumentary-system/ contagious-ecthyma/overview-of-contagious-ecthyma 